\title{
LOW GENETIC DIVERSITY IN Wolbachia-INFECTED Culex quinquefasciatus (DIPTERA: CULICIDAE) FROM BRAZIL AND ARGENTINA
}

Sirlei Antunes MORAIS(1), Fábio de ALMEIDA(2,3), Lincoln SUESDEK(2,3) \& Mauro Toledo MARRELLI(1)

\begin{abstract}
SUMMARY
Culex quinquefasciatus is a vector of human pathogens, including filarial nematodes and several viruses. Although its epidemiological relevance is known to vary across geographical regions, an understanding of its population genetic structure is still incipient. In light of this, we evaluated the genetic diversity of $C x$. quinquefasciatus and $C x$. pipiens x $C x$. quinquefasciatus hybrids collected from nine localities in Brazil and one site in Argentina. We used mitochondrial genes coxl and nd4, along with the coxA and wsp genes of the maternally-inherited Wolbachia endosymbiont. The $n d 4$ fragment was invariant between samples, whilst cox 1 exhibited four haplotypes that separated two types of $C x$. quinquefasciatus, one clustered in southern Brazil. Low sequence diversity was generally observed, being discussed. Both Brazilian and Argentinian mosquitoes were infected with a single Wolbachia strain. As reported in previous studies with these populations, coxl and $n d 4$ diversity is not congruent with the population structure revealed by nuclear markers or alar morphology. Future $C x$. quinquefasciatus research should, if possible, evaluate mtDNA diversity in light of other markers.
\end{abstract}

KEYWORDS: Culex quinquefasciatus; Genetic diversity; Mitochondrial markers; Wolbachia.

\section{INTRODUCTION}

Although Culex quinquefasciatus Say (Diptera: Culicidae) is a vector of human pathogens, including agents for filariasis and several arboviruses, its epidemiological importance varies considerably among regions ${ }^{14}$. In equatorial-tropical regions, the species is reported as the primary vector of Wuchereria bancrofti in the transmission cycle of lymphatic filariasis ${ }^{36}$. In subtropical and temperate urban areas, it is implicated as the primary vector of West Nile Virus ${ }^{23}$ and other arboviruses ${ }^{11}$.

Species of the Culex pipiens complex share morphological similarities and generally proliferate in human settlements, with $C x$. quinquefasciatus adapted to tropical and subtropical areas and $C x$. pipiens to temperate regions. Their ranges overlap in intermediate areas, resulting in genetic introgression and hybridization ${ }^{10}$. In Brazil, $C x$. quinquefasciatus has an expansive distribution, including in almost all major cities ${ }^{28}$. Hybrids of quinquefasciatus/pipiens occur in Uruguay and central Argentina, whilst Cx. pipiens occupies regions southward into Argentina ${ }^{4,30}$.

Because they are vectors of both urban and rural diseases, members of the pipiens subgroup have been targets of population control programs worldwide, with anthropophilic species killed by contact with chemical or biological reagents ${ }^{19}$. However, these populations often adapt resistance to these measures, with the selected organisms eventually expanding into different biogeographic regions.

In addition to pressure from control initiatives, these mosquitoes are often infected by endosymbionts such as Wolbachia pipientis rickettsies, which are associated with cytoplasmatic incompatibility $(\mathrm{CI})^{3}$. Under CI dynamics, crosses between infected males with non-infected females produce eggs with decreased viability. Progenies originating from infected females and either infected or non-infected males are normally fertile. However, research has shown that offspring of individuals infected with different Wolbachia strains may be infertile ${ }^{24}$. Consequently, infected females have a reproductive advantage that leads to the expansion of infection in populations.

Recently, ALMEIDA ${ }^{2}$ showed that infection by a single Wolbachia strain was ubiquitous in all $C x$. quinquefasciatus samples tested from São Paulo City, Brazil. Among the pipiens subgroup, insecticide-resistant populations tend to be infected with higher Wolbachia densities ${ }^{12}$. It has been posited that a low efficiency of Wolbachia control may be related to mosquito immunity factors. In view of this, the manipulation of Wolbachia infections has generated enthusiasm in the field of vector control ${ }^{21}$.

Despite its epidemiological relevance, population genetics data for $C x$. quinquefasciatus are still sparse. We thus sought to analyze

(1) Departamento de Epidemiologia, Faculdade de Saúde Pública, Universidade de São Paulo, São Paulo, SP, Brazil.

(2) Seção Parasitologia, Instituto Butantan, São Paulo, SP, Brazil.

(3) Biologia da Relação Patógeno-Hospedeiro, Instituto de Ciências Biomédicas, Universidade de São Paulo, São Paulo, SP, Brazil.

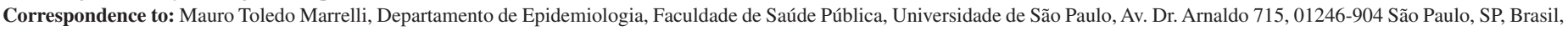
Tel: +55-11-30617922. E-mail: mmarelli@usp.br. 


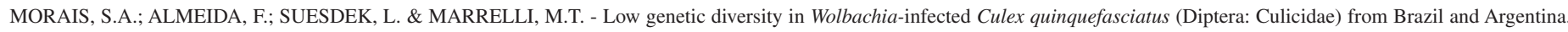
Rev. Inst. Med. Trop. Sao Paulo, 54(6): 325-9, 2012.

the genetic diversity of $C x$. quinquefasciatus populations from urban areas of Brazil and central Argentina using cytochrome $c$ oxidase subunit I (coxl) and NADH dehydrogenase subunit $4(n d 4)$ and these populations' patterns of Wolbachia pipientis infection through analysis of the Wolbachia surface protein (wsp) and cytochrome $c$ oxidase subunit I ( $\operatorname{cox} A)$.

\section{MATERIALS AND METHODS}

Mosquitoes. Adult mosquitoes were collected by aspiration ${ }^{32}$ near residual-water channels during February and March 2008 in the Brazilian municipalities of Teresina $\left(5^{\circ} \mathrm{S}\right)$, Recife $\left(8^{\circ} \mathrm{S}\right)$, Rio Branco $\left(9^{\circ} \mathrm{S}\right)$, Pariquera-Açu $\left(24^{\circ} \mathrm{S}\right)$, Pelotas $\left(31^{\circ} \mathrm{S}\right)$, Chapecó $\left(27^{\circ} \mathrm{S}\right)$, Pontes e Lacerda $\left(15^{\circ} \mathrm{S}\right)$, Santa Vitória do Palmar $\left(33^{\circ} \mathrm{S}\right)$ and São Paulo $\left(23^{\circ} \mathrm{S}\right)$, and in the Argentinian city of La Plata $\left(34^{\circ} \mathrm{S}\right)$ (Fig. 1). Samples were stored in individual tubes on silica gel until processing. Thirty specimens from each locality (15 males and 15 females) were identified following taxonomic keys ${ }^{15}$ and subsequently analyzed genetically.

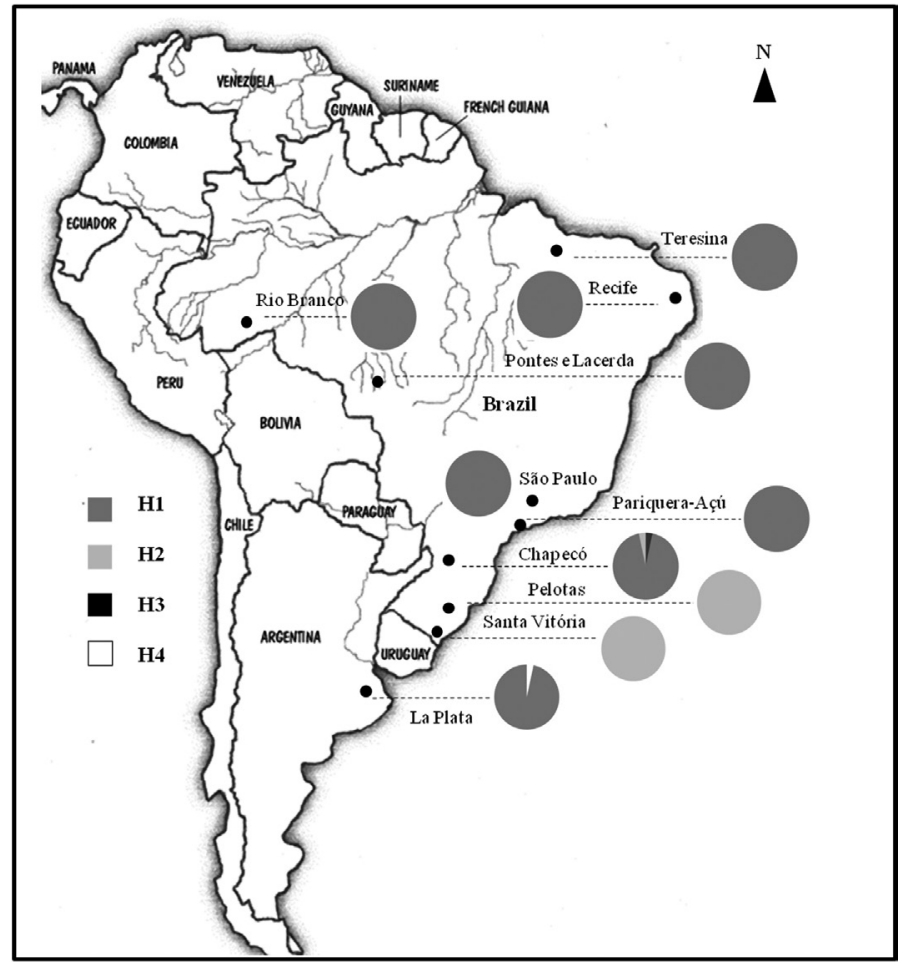

Fig. 1 - Map of South America with mosquito collection sites and distribution of four cox 1 haplotypes in Brazil and Argentina.

DNA extraction and amplification of mitochondrial genes. Genomic DNA was isolated from individual mosquitoes using DNeasy® Blood \& Tissue kits (Qiagen) following the manufacturer's instructions. DNA was eluted to a final volume of $100 \mu \mathrm{L}$ and stored at $-20{ }^{\circ} \mathrm{C}$ until polymerase chain reaction (PCR). Internal primers were designed to shotgun-amplify the complete 1260-bp coxl amplicon: two smaller fragments ( 700-bp) were assembled following amplification using primers pairs Fly $10^{27}+$ coxF1 (5' '-TTT GAG CTC ATC ATA TAT TTA-3') and UEA $3^{41}+$ coxR2 (5'-GCT CGT GTA TCA ACA TCT-3'). Primers ND4+/ND4- ${ }^{16}$ were used to amplify the $n d 4$ gene.
PCR was performed in a final volume of $50 \mu \mathrm{L}$, which included $2 \mathrm{mM} \mathrm{MgCl}$, $20 \mathrm{mM}$ Tris- $\mathrm{HCl}$ (pH 8.4), $50 \mathrm{mM} \mathrm{KCl}, 0.5 \mathrm{mM}$ of each primer, $0.2 \mathrm{mM}$ dNTP mix, $1 \mathrm{U}$ Taq DNA polymerase (Invitrogen), and 5-10 ng genomic DNA. The thermocycler program was configured for an initial denaturation step at $94{ }^{\circ} \mathrm{C}$ five min, followed by 35 amplification cycles $\left(94{ }^{\circ} \mathrm{C} / 60 \mathrm{~s}, 50{ }^{\circ} \mathrm{C} / 60 \mathrm{~s}\right.$, and $\left.72{ }^{\circ} \mathrm{C} / 60 \mathrm{~s}\right)$ and a final elongation at $72{ }^{\circ} \mathrm{C}$ for $10 \mathrm{~min}$.

Amplification of Wolbachia genes (wsp and coxA). Mosquito samples from Teresina, Rio Branco, Santa Vitória and La Plata were tested for Wolbachia using the total DNA preparations employed for PCR above. The PCR conditions described in ZHOU et $a l .{ }^{42}$ and SANOGO et $a l .{ }^{38}$ were used to amplify $w s p$. Samples from each mosquito population were then submitted to PCR-amplification of bacterial cytochrome $c$ oxidase $(\operatorname{cox} A)$ to detect population/strain polymorphism using primers and conditions described in BALDO et al. ${ }^{6}$.

DNA sequencing and sequence analyses. Amplified fragments were sequenced using BigDye TM Terminator 3.1 (Applied Biosystems), following the manufacturer's recommendations and directly sequenced on an ABI prism®3100. Sequences were analyzed using Chromas (Technelysium Pty), aligned with Clustalw2 (EBI) and edited with the software Geneious Pro 5.5.7 (Biomatters) and BioEdit 7.0.9 (Ibis Biosciences). Structural fragments were evaluated using ORF Finder (NCBI) and protein-structure predictions were developed initially through PSIPRED and then queried in the InterPro databases (NCBI). Pairwise, similarity data and genetic distance were calculated with Geneious Pro 5.5.7. Statistical data, such as haplotypes diversity $(\mathrm{Hd})$ and nucleotides diversity per site $(\pi)$ were tabulated from DnaSP v5.

\section{RESULTS}

Mosquito samples. Culex quinquefasciatus were caught almost exclusively in each mosquito collection. Samples were killed and preliminarily identified in the field, stored in individual tubes with silica gel (100 adult females and 100 adult males) and transported to the laboratory of the Faculdade de Saúde Pública USP, in São Paulo. At least two adult male and female vouchers from each locality were mounted and deposited in the Coleção de Referência da Faculdade de Saúde Pública USP, under access numbers E-13706 to E-13729. An equal number of females and males $(\mathrm{N}=30)$ from each locality were separated for molecular analyses.

Mitochondrial molecular markers. Amplification of the nd4 gene produced fragments of 321-bp (after primer trimming) (GenBank accession number GQ255653). This fragment showed high A+T content (72.6\%) and $100 \%$ sequence identity among samples. The 1260-bp cox1 fragment was comprised of four haplotypes ( $\mathrm{H} 1, \mathrm{H} 2, \mathrm{H} 3$ and $\mathrm{H} 4)$, whose geographical distribution is shown in Figure 1. The sequences were deposited in GenBank, under accession numbers: GQ255650 (H1), GQ255651 (H2), GQ255649 (H3) and GQ255648 (H4).

The H1 haplotype was that with the highest frequency $(76.6 \%)$, followed by $\mathrm{H} 2(22.6 \%)$ and $\mathrm{H} 3$ and $\mathrm{H} 4(0.4 \%)$. Haplotypes $\mathrm{H} 3$ and $\mathrm{H} 4$ each contained one mutation in a single mosquito sample. To confirm the singleton status of these haplotypes, we repeated PCR and sequencing from the same genomic DNA. The alignment of the four haplotypes showed $99.7 \%$ genetic identity among geographic samples. Genetic 


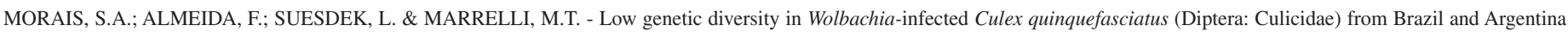
Rev. Inst. Med. Trop. Sao Paulo, 54(6): 325-9, 2012

diversity of the coxl fragment was low: haplotype diversity $(\mathrm{Hd}=0.636)$ and nucleotide diversity per site $(\pi=0.00091)$. The $\mathrm{H} 2$ haplotype was restricted to southern Brazil (Santa Vitória and Pelotas), but was also detected in a mosquito sample from Chapecó City.

Genic products. Prediction analyses confirmed the proteins cytochrome c oxidase 1 (COX1 EC1.9.3.1) and NADH dehydrogenase 4 (NADH4 EC1.6.5.3) as products of the coxl and $n d 4$ fragments, respectively. Analyses showed that the $\operatorname{cox} 1$ transition $(\mathrm{C} \rightarrow \mathrm{T})$ detected in a La Plata sample $(\mathrm{H} 4)$ results in modification of the primary protein structure throughout the domain region. This amino acid modification did not show identity with other coxl enzymes. Other transitions in haplotypes $\mathrm{H} 1, \mathrm{H} 2$ and $\mathrm{H} 3$ did not produce changes in the primary protein structure. Pairwise comparisons of coxl resulted in $100 \%$ identity with $C x$. pipiens and $C x$. quinquefasciatus from other regions of the world, indicating homology and conserved functional domain.

Wolbachia infection. The Wolbachia pipientis wsp and coxA amplicon sizes were 504-bp (61\% A+T) and 478-bp (62.6\% A+T), respectively. All sequences for both genes were identical in all samples analyzed and have been deposited under GenBank under accession numbers HM563687 (wsp) and HM563686 (coxA). In comparison to the Wolbachia genome available from GenBank (accession number AM999887), the wsp sequence was $100 \%$ similar to the homologous region in the Wolbachia wPip strain, an endosymbiont of Cx. quinquefasciatus. The coxA sequence was also $100 \%$ similar to the homologous region of cytochrome $c$ oxidase subunit 1 of the wPip strain.

\section{DISCUSSION}

Comparative analyzes with the partial $n d 4$ of $C x$. quinquefasciatus showed 100\% identity with mosquitoes from South Africa (AY793692) and Thailand (AY793692), and a one-base substitution in comparison to sequences from Riverside USA (AY793693). Although the complete Cx. quinquefasciatus nd4 sequence is 1343-bp long (HQ724617), studies commonly use the primer pair used here (nd4+/nd4-) to produce an amplicon of approximately 350-bp located in the gene's central portion. This region has been widely used in others culicid mosquitoes in studies of genetic diversity, systematics and phylogeny, being that the $C x$. quinquefasciatus nd4 sequences yielded diversity indices higher for both Anopheles ${ }^{31}$ and Aedes ${ }^{26}$ genera $(\mathrm{Hd}=0.895 ; \pi=0.0127)$. The low variation seen in the $n d 4$ gene highlights its conservation and tendency toward homoplasmy in $C x$. quinquefasciatus.

The variation seen in the four $C x$. quinquefasciatus coxl haplotypes is incongruent with the results from the ace 2 intron and for mosquitoes of hybrid origin (with $C x$. pipiens) found by MORAIS et al. ${ }^{30}$, potentially because ace 2 mutates slower than $\operatorname{cox} l^{20}$. This suggests that mitochondrial DNA does not distinguish taxa within the pipiens subgroup. Sequences of coxl show both intra and inter-specific polymorphism, indicating that taxonomic diagnoses should include nuclear markers to avoid overestimates of diversity in $C x$. quinquefasciatus-pipiens populations. However, mitochondrial markers identified different $C x$. quinquefasciatus genetic types, including the Brazilian groupings.

The H1 haplotype is broadly distributed throughout the Brazilian tropics and in La Plata. It shares identity with the $C x$. quinquefasciatus of tropical India (GenBank acc. no. FN395201). The H2 haplotype forms a population group, with a latitudinal range between 31 and $33^{\circ} \mathrm{S}$ in Brazil. It shares identity with $C x$. pipiens coxl sequences from Ohio (DQ360492), Cx. pipiens (FN395187) and Cx. p. f. molestus (FN395179) from Russia, Cx. p. pallens (FN395203) from Japan and Cx. quinquefasciatus (DQ181446) from Puerto Rico.

The H2 haplotype is found predominantly in southern Brazil. Its restriction to this region may be a consequence of founder effects. The low frequency of $\mathrm{H} 2$ in Chapecó suggests that this city may represent the limits of haplotype's northern distribution. However, the La Plata population, which is genetically confirmed as a hybrid ${ }^{30}$, contains individuals sharing $n d 4$ and coxl genes with pure $C x$. quinquefasciatus elsewhere. We suggest that reproductive isolation is incomplete within the pipiens subgroup and that this affects the taxonomic resolution usually provided by mitochondrial genes, including gene $\operatorname{cox} 1$ barcode.

The differences between haplotypes $\mathrm{H} 3$ and $\mathrm{H} 4$ are insufficient to ascertain their relevance to intra-specific divergence or their relationship with mosquitoes from other parts of the world. Single mutations were also found in coxl sequences by COOK et al. ${ }^{9}$ and reflect the polymorphic character of this gene.

Prediction tests showed that the four-base substitutions detected in coxl are transitions. Three of these are synonymous and two form population groupings. Transitions and synonymous substitutions were also found by NAVAJAS et al. ${ }^{33}$ in other insects coxl. According to those authors, changes in the base composition of mitochondrial genes occur most frequently through synonymous transitions, without detectable effects on gene functioning. However, the sequences enabled the identification of divergence and gene flow dynamics in biogeographically distinct populations.

The low diversity of $C x$. quinquefasciatus and $C x$. pipiens mitochondrial genes has been reported by GUILLEMAUD et al. ${ }^{17}$. HASAN et al. ${ }^{18}$ also found low diversity $(\mathrm{Hd}=0.502$ and $\pi=0.0007)$ in the $C x$. quinquefasciatus cox 2 of populations from central Bangladesh, potentially a result of a recent common mitochondrial ancestor. Such data may also be explained by the recent and rapid expansion of these species (assisted by human migration and population growth) and successive bottlenecks caused by control measures in urban areas ${ }^{13}$.

Culex quinquefasciatus populations have been significantly impacted by control programs in Brazil, particularly in northern and northeastern equatorial regions, where the species is the primary vector of lymphatic filariasis and dirofilariasis ${ }^{1}$. The regions' low altitude, hot and humid climate and constant thermal amplitude facilitate both the development of the heartworm pathogen and the hematophagy of Culex vectors throughout the year ${ }^{25}$.

Unlike, vector control programs are less intense in southern Brazil due to the humid subtropical climate and high peaks of thermal amplitude. Although Culex populations in these areas have shown resistance to thermal shock, they suffer reduced numbers of over-wintering individuals and lower metabolic activity during cold months ${ }^{37}$. Although no cases of heartworm have been identified from southern Brazil, there are records of encephalitis and arbovirosis ${ }^{8}$. In Argentina, members of the pipiens complex are implicated as vectors of arboviruses, such as Saint Louis Encephalitis ${ }^{11}$. 
MORAIS, S.A.; ALMEIDA, F.; SUESDEK, L. \& MARRELLI, M.T. - Low genetic diversity in Wolbachia-infected Culex quinquefasciatus (Diptera: Culicidae) from Brazil and Argentina. Rev. Inst. Med. Trop. Sao Paulo, 54(6): 325-9, 2012.

Due to the epidemiological importance of Culex, vector-control programs have been organized in urban and rural areas for decades. These have involved countless chemical insecticides such as pyrethroids, Dichloro-diphenyltrichloroethane (DDT) and their derivades 5 . Organophosphates, Bacillus thuringiensis ${ }^{7}$ and Bacillus sphaericus ${ }^{29}$ larvicides have also been used. The exposure of mosquito populations to insecticides often confers resistance ${ }^{40}$ and the expansion of resistant individuals can explain population-level selective sweeps ${ }^{34}$.

On another view, Brazilian $C x$. quinquefasciatus populations share identical $n d 4$ sequences to those of RASGON et al. ${ }^{35}$ in North America (GenBank acc. no. AY793688) and parts of Asia (AY793691), but are from 5 to $6 \%$ divergent from South African populations (AY793694). These authors suggest that mitochondrial diversity may be related to Wolbachia infection: the American and Asian samples, which are infected, have low diversity, whilst the uninfected populations of South Africa have higher mitochondrial variation. All Culex samples are apparently infected by a single Wolbachia strain because of the invariant wsp and coxA sequences. This appears to be $w$ Pip, with which the Wolbachia infections herein share sequence similarity and similar hosts: $C x$. quinquefasciatus and Cx. pipiens.

The fact that, despite being geographically scattered, all populations sampled herein share the same Wolbachia strain may be explained by host-endosymbiont specificity, as pointed out by WERREN et al. ${ }^{39}$. The genetic homogeneity observed among Wolbachia samples may also indicate that this endosymbiont only recently infected these Culex populations.

Culex quinquefasciatus appears to possess two mitochondrial types in Brazil. This fact should be taken into consideration in investigations of disease distribution and in aspects of blood-hosts in those locations. Recent studies suggest that feeding preferences may be influenced by genetic factors ${ }^{22}$.

\section{RESUMO}

\section{Baixa diversidade genética em Culex quinquefasciatus (Diptera: Culicidae) infectado por Wolbachia do Brasil e Argentina}

Culex quinquefasciatus é vetor de patógenos humanos, incluindo nematódeos filarídeos e vários vírus. Embora a sua relevância epidemiológica varie entre as diferentes regiões geográficas, o conhecimento da estrutura genética da população é ainda incipiente. Em vista disso, foram avaliados os níveis de diversidade genética de $C x$. quinquefasciatus e de híbridos $C x$. quinquefasciatus x $C x$. pipiens de nove cidades do Brasil e em La Plata, na Argentina. Para os testes foram utilizados fragmentos dos genes mitocondriais coxl e nd4, juntamente com coxA e wsp do endossimbionte Wolbachia, herdado maternalmente. $\mathrm{O}$ fragmento $n d 4$ não apresentou variação entre as amostras, e o coxl exibiu quatro haplótipos que separaram dois tipos de Cx. quinquefasciatus, com um deles agrupado no sul do Brasil. Os dados de sequência mostraram baixa diversidade, sendo esta discutida. Ambas as amostras de mosquitos brasileiros e argentinos estão infectados com uma única cepa de Wolbachia. A diversidade apresentada por $n d 4$ e coxl não é congruente com a estrutura da população revelada por marcadores nucleares e morfologia alar de estudos anteriores com estas mesmas populações. Pesquisas com $C x$. quinquefasciatus devem, se possível, avaliar a diversidade por DNA mitocondrial na luz de outros marcadores.

\section{ACKNOWLEDGMENTS}

To Dr. Almério de Castro Gomes (Faculdade de Saúde Pública, Universidade de São Paulo, Brazil) for providing mosquito samples from Teresina. Gustavo Rossi (Centro de Estudios Parasitologicos y de Vectores, La Plata, Argentina) for providing specimens from La Plata. We also thank Ministério da Saúde - FUNASA and Secretaria Estadual de Saúde, municipalities of Pelotas and Rio Branco for helping us during the field works. This investigation was supported by FAPESP (grants 05/50225-2 and 06/02622-5). S.A.M. is fellow of FAPESP (06/57272-9). F.A is fellow of CNPq (142766/2008-9).

\section{REFERENCES}

1. Ahid SMM, Vasconcelos PSS, Lourenço-de-Oliveira R. Vector competence of Culex quinquefasciatus Say from different regions of Brazil to Dirofilaria immitis. Mem Inst Oswaldo Cruz. 2000;95:769-75.

2. Almeida F. Análise comparativa de Culex quinquefasciatus infectados e não infectados [dissertação]. São Paulo: Universidade de São Paulo, Instituto de Ciências Biomédicas; 2008.

3. Almeida F, Moura AS, Cardoso AF, Winter CE. Bijovsky AT. Suesdek L. Effects of Wolbachia on fitness of Culex quinquefasciatus (Diptera; Culicidae). Infect Genet Evol. 2011;11:2138-43.

4. Almirón WR, Humeres SG, Gardenal CN. Distribution and hybridization between Culex pipiens and Culex quinquefasciatus (Diptera: Culicidae) in Argentina. Mem Inst Oswaldo Cruz. 1995;90:469-73.

5. Alves SN, Serrão JE, Melo AL. Alterations in the fat body and midgut of Culex quinquefasciatus larvae following exposure to different insecticides. Micron. 2010;41:592-7.

6. Baldo L, Dunning Hotopp JC, Jolley KA, Bordenstein SR, Biber SA, Choudhury RR, et al. Multilocus sequence typing system for the Endosymbiont Wolbachia pipientis. Appl Environ Microbiol. 2006;72:7098-110.

7. Barbosa RMR, Regis L, Vasconcelos R, Leal WS. Culex mosquitoes (Diptera: Culicidae) egg laying in traps loaded with Bacillus thuringiensis variety israelensis and baited with skatole. J Med Entomol. 2010;47:345-8.

8. Cardoso JC, Paula MB, Fernandes A, Santos E, Almeida MAB, Fonseca DF, et al. Novos registros e potencial epidemiológico de algumas espécies de mosquitos (Diptera, Culicidae) no estado do Rio Grande do Sul, Brasil. Rev Soc Bras Med Trop. 2010;43:552-6.

9. Cook S, Bennett SN, Holmes EC, De Chesse R, Moureau G, Lamballerie X. Isolation of a new strain of the flavivirus cell fusing agent virus in a natural mosquito population from Puerto Rico. J Gen Virol. 2006;87(Pt 4):735-48.

10. Cornel AJ, McAbee RD, Rasgon J, Stanich MA, Scott TW, Coetzee M. Differences in extent of genetic introgression between sympatric Culex pipiens and Culex quinquefasciatus (Diptera: Culicidae) in California and South Africa. J Med Entomol. 2003;40:36-51.

11. Diaz LA, Nemeth NM, Bowen RA, Almiron WR, Contigiani MS. Comparison of Argentinean Saint Louis Encephalitis Virus non-epidemic and epidemic strain infections in an avian model. PLoS Negl Trop Dis. 2011;5:e1177.

12. Echaubard P, Duron O, Agnew P, Sidobre C, Noël V, Weill M, et al. Rapid evolution of Wolbachia density in insecticide resistant Culex pipiens. Heredity (Edinb). 2011;104:15-9. 
13. Fonseca DM, Lapointe DA, Fleischer RC. Bottlenecks and multiple introductions: population genetics of the vector of avian malaria in Hawaii. Mol Ecol. 2000;9:180314.

14. Fonseca DM, Smith JL, Wilkerson RC, Fleischer RC. Pathways of expansion and multiple introductions illustrated by large genetic differentiation among worldwide populations of the southern house mosquito. Am J Trop Med Hyg. 2006;74:284-9.

15. Forattini OP. Culicidologia médica. São Paulo: EDUSP; 2002.

16. Gorrochotegui-Escalante N, Munoz ML, Fernandez-Salas I, Beaty BJ, Black IV WC. Genetic isolation by distance among Aedes aegypti populations along the northeastern coast of Mexico. Am J Trop Med Hyg. 2000;62:200-9.

17. Guillemaud T, Pasteur N, Rousset F. Contrasting levels of variability between cytoplasmic genomes and incompatibility types in the mosquito Culex pipiens. Proc Biol Sci. 1997;264:245-51.

18. Hasan AU, Suguri S, Ahmed SM, Fujimoto C, Harada M, Rahman SM, et al. Molecular phylogeography of Culex quinquefasciatus mosquitoes in central Bangladesh. Acta Trop. 2009;112:106-14

19. Hemingway J, Hawkes N, Prapanthadara L, Jayawardenal KGI, Ranson H. The role of gene splicing, gene amplification and regulation in mosquito insecticide resistance. Philos Trans R Soc Lond B Biol Sci. 1998;353:1695-9.

20. Hemmerter S, Slapeta J, Beebe NM. Resolving genetic diversity in Australasian Culex mosquitoes: incongruence between the mitochondrial cytochrome c oxidase I and nuclear acetylcholine esterase 2. Mol Phylogenet Evol. 2009;50:317-25.

21. Iturbe-Ormaetxe I, Walker T, O' Neill SL. Wolbachia and the biological control of mosquito-borne disease. EMBO Rep. 2011;12:508-18.

22. Kilpatrick AM, Kramer LD, Jones MJ, Marra PP, Daszak P, Fonseca DM. Genetic influences on mosquito feeding behavior and the emergence of zoonotic pathogens. Am J Trop Med Hyg. 2007;77:667-71

23. Kwan JL, Kluh S, Madon MB, Reisen WK. West Nile virus emergence and persistence in Los Angeles, California, 2003-2008. Am J Trop Med Hyg. 2010;83:400-12.

24. Laven H. A possible model for speciation by cytoplasmic isolation in the Culex pipiens complex. Bull World Health Org. 1967;37:263-6.

25. Labarthe N, Guerrero J. Epidemiology of heartworm: what is happening in South America and Mexico? Vet Parasitol. 2005;133:149-56.

26. Llinás GA, Gardenal CN. Introduction of different lineages of Aedes aegypti in Argentina. J Am Mosq Control Assoc. 2011;27:429-32.

27. Lunt DH, Zhang DX, Szymura JM, Hewltt OM. The insect cytochrome oxidase gene: evolutionary patterns and conserved primers for phylogenetic studies. Insect Mol Biol. 1996:5:153-65.
28. Morais SA, Marrelli MT, Natal D. Aspectos da distribuição de Culex (Culex) quinquefasciatus Say (Diptera, Culicidae) na região do rio Pinheiros, na cidade de São Paulo, estado de São Paulo, Brasil. Rev Bras Entomol. 2006;50:413-8.

29. Morais SA, Marrelli MT, Natal D. Observações sobre aplicações de controle em ecótopo com alta infestação de Culex quinquefasciatus Say (Diptera, Culicidae). Rev Bras Entomol. 2007;51:246-51

30. Morais SA, Moratore C, Suesdek L, Marrelli MT. Genetic-morphometric variation in Culex quinquefasciatus from Brazil and La Plata, Argentina. Mem Inst Oswaldo Cruz. 2010;105:672-6.

31. Moutinho PR, Gil LHS, Cruz RP, Ribolla PEM. Population dynamics, structure and behavior of Anopheles darlingi in a rural settlement in the Amazon rainforest of Acre, Brazil. Malaria J. 2011;10:174.

32. Nasci RS. A light weight battery powered aspirator for collecting resting mosquitoes in the field. Mosq News. 1981;41:808-11.

33. Navajas M, Fournier D, Lagnel J, Gutierrez J, Boursot P. Mitochondrial COI sequences in mites: evidence for variations in base composition. Insect Mol Biol. 1996;5:281-5.

34. Pasteur N, Raymond M. Insecticide resistance genes in mosquitoes: their mutations, migration, and selection in field populations. J. Hered. 1996;87:444-9.

35. Rasgon JL, Cornel AJ, Scott TW. Evolutionary history of a mosquito endosymbiont revealed through mitochondrial hitchhiking. Proc Biol Sci. 2006;273:1603-11.

36. Regis L, Silva-Filha MHNL, Oliveira CMF, Rios EM, Silva SB, Furtado AF. Integrated control measures against Culex quinquefasciatus, the vector of filariasis in Recife. Mem Inst Oswaldo Cruz. 1995;90:115-9.

37. Ribeiro PB, Costa PRP, Loeck AE, Vianna EES, Silveira Júnior P. Exigências térmicas de Culex quinquefasciatus (Diptera, Culicidae) em Pelotas, Rio Grande do Sul, Brasil. Iheringia Sér Zool. 2004;94:177-80.

38. Sanogo YO, Dobson SL, Bordenstein SR, Novak RJ. Disruption of the Wolbachia surface protein gene $w s p B$ by a transposable element in mosquitoes of the Culex pipiens complex (Diptera, Culicidae). Insect Mol Biol. 2007;16:143-54

39. Werren JH, Baldo L, Clark ME. Wolbachia: master manipulators of invertebrate biology. Nat Rev Microbiol. 2008;6:741-51

40. Xu Q, Liu H, Zhang L, Liu N. Resistance in the mosquito Culex quinquefasciatus, and possible mechanisms for resistance. Pest Manag Sci. 2005;61:1096-102.

41. Zhang DX, Hewitt GM. Assessment of the universality and utility of a set of conserved mitochondrial COI primers in insects. Insect Mol Biol. 1997;6:143-50.

42. Zhou W, Rousset F, O'Neill S. Phylogeny and PCR-based classification of Wolbachic strains using wsp gene sequences. Proc Biol Sci. 1998;265:509-15.

Received: 10 October 2011

Accepted: 4 June 2012 